\title{
An Integrated Model for M-Banking Adoption in Saudi Arabia
}

\author{
Abdullah Baabdullah \\ Department of Management Information Systems \\ King Abdulaziz University, Jeddah, Saudi Arabia \\ baabdullah@kau.edu.sa \\ Ali Abdallah Alalwan \\ Amman College of Banking and Financial Sciences \\ Al-Balqa' Applied University, Amman, Jordan \\ alwan.a.a.ali@gmail.com
}

Nripendra P. Rana

School of Management

Swansea University Bay Campus

Fabian Way, Swansea, SA1 8EN, UK

Tel: +44(0) 1792295179

nrananp@gmail.com

PushP P. Patil

School of Management

Swansea University Bay Campus

Fabian Way, Swansea, SA1 8EN, UK

pushpppatil@gmail.com

Yogesh K. Dwivedi

School of Management

Swansea University Bay campus

Fabian Way, Swansea, SA1 8EN, UK

ykdwivedi@gmail.com

\begin{abstract}
Purpose - This study aims to identify and examine the most important factors that could predict the Saudi customer's continued intention towards adoption of mobile banking.

Design/methodology/approach - The proposed conceptual model was based on the Technology Acceptance Model (TAM) and Task-Technology Fit (TTF) model. This is also expanded by considering two additional factors: perceived privacy and perceived security. By using a self-administered questionnaire, the data was collected from a convenience sample of Saudi banking customers from different parts of Saudi Arabia.
\end{abstract}

Findings - The main results based on structural equation modelling analyses supported the impact of perceived privacy, perceived security, perceived usefulness, and task-technology fit on the customers' continued intention to use mobile banking.

Research limitations/implications - The moderation influence of the demographic factors (i.e. age, gender, income level, educational level) was not tested. The data was also collected using a self-report questionnaire; however, it would be more accurate to utilise more statistics from the bank database about the users of m-banking. 
Originality/value - This study represents a worthy attempt to test such novel technology (mbanking) in the KSA where there is a scarcity of literature. A considerable theoretical contribution was also made by integrating the TTF model with the TAM in addition to consider privacy and security in one single model. Moreover, considering both perceived privacy and security in the current model creates an accurate picture about the adoption of $\mathrm{m}$ banking especially as there are a limited number of m-banking studies that have considered privacy and security alongside the TTF model and TAM in the same model.

Keywords: Mobile banking, TTF, TAM, Saudi Arabia, Intention, Adoption

\section{Introduction}

Mobile banking (m-banking) addresses the essential restriction of e-banking as it decreases the user's requirement to merely a mobile phone rather than relying on a PC device with Internet connections (Adholiya et al., 2012; Alalwan et al., 2016; Al-Otaibi et al., 2018; Laukkanen and Pasanen, 2008; Mullan et al., 2017; Sharma and Al-Muharrami, 2018; Zhou, 2012; Zhou, 2011). For this reason, mobile devices have increasingly become instruments that consumers adopt for banking services such as making payments, checking balances and statements, viewing account details, viewing and cancelling Direct Debits, and easily identifying user transactions (Alalwan et al., 2017; Coetzee and Eksteen, 2011; Jeong and Yoon, 2013; Kim et al., 2009; Lee and Chung, 2009; Priya et al., 2018; Santander Bank, 2017; Singh and Srivastava, 2018; Slade et al., 2015a; Slade et al., 2015b).

According to the Board of Governors of the Federal Reserve System (2013), among mobile phone users, the rate of m-banking adoption increased from $21 \%$ to $28 \%$ between 2011 and 2012. Furthermore, among owners of smartphones, the rate of using m-banking went up from $42 \%$ to $48 \%$ between 2011 and 2012. Moreover, according to the British Bankers' Association (2015), there is a notable growth with m-banking as payment via apps, which ascended in 2015 by $54 \%$ with a value of $£ 347 \mathrm{~m}$. Interestingly, China has witnessed a radical increase in the adoption of m-banking since 2015. As such, the gross transaction volume which was done through using m-banking soared from 65.5 trillion Yuan in 2015 to reach 179 trillion Yuan in 2017. In addition, the transaction volume is supposed to increase in 2018 to reach 244.9 trillion Yuan (Statista, 2017).

The steadily growing adoption of m-banking cannot merely be interpreted as being due to the ability of m-banking to provide accessibility to financial services remotely, but also as being due to the unique characteristics of mobiles used in m-banking which support the issue of personal security (Coetzee and Eksteen, 2011; Jahangir and Begum, 2008; Jeong and Yoon, 
2013; Shareef et al., 2018). For instance, through using an iPhone, the user can upload a securely protected photo of his/her debit/credit card and use it in financial transactions and payments without the need to hold physical cards anymore (Cellan-Jones, 2016; Kaymaz, 2017; Santander Bank, 2017). Furthermore, with a passcode and finger ID check, there is no possibility of a third party stealing or penetrating the device (Apple Pay, 2017; Deloitte LLP UK member firm of DTT, 2016; Martin, 2016). These multiple shields of privacy and security have increased the reliance of users on their mobiles while doing m-banking and, hence, maximised their continued intention to use an m-banking service (Bannister, 2014; Barclays, 2017; Pay by Bank app, 2016; Rolfe, 2015).

M-banking technology comprises several kinds of benefits that really accelerate customers' continued intention to use such technology. For instance, using m-banking helps customers to access a wide range of banking transactions (i.e. balance enquiries, fund transfers, payment of bills) without time and place restrictions (Lee et al., 2015; Lin, 2011; Lin, 2013). This, in turn, reduces the associated cost and time of launching such banking services, and accordingly, maximises the level of perceived usefulness in using m-banking (Alalwan et al., 2016). Further, using m-banking could also help banks to reach customers who reside in a particular area that has a weak Internet infrastructure or difficulties in establishing bank branches (Cruz et al., 2010; Mishra and Bisht, 2013; Shareef et al., 2012; Shareef et al., 2014). By the same token, due to the growth of m-banking espousal at an international level, the literature of the information systems field has investigated the factors that increase the continued intention to use m-banking (Afshan and Sharif, 2016; Akturan and Tezcan; 2012; Alalwan et al., 2016; Isac, 2013).

On the other hand, there are a number of barriers that could hinder customers' intention or continued intention to use m-banking. For example, customers in developing countries such as Saudi Arabia display habitual behaviour in accessing banking transactions via traditional channels, and therefore, there is always difficulty in persuading such bank clients to use mbanking (Laukkanen et al., 2007; Laukkanen and Cruz, 2009). Customers are also concerned about security and privacy issues when they are in process of using m-banking. For instance, problems related to the initial cost of using m-banking or having Internet access are reported by Yang (2009), Yu (2012), and Hanafizadeh et al. (2014) to be the main barriers hindering the customer's willingness to use m-banking. Other m-banking researchers (i.e. Hanafizadeh et al., 2014; Jeong and Yoon, 2013) have reported the negative impact of perceived risk in 
hindering the adoption of m-banking as well. Furthermore, customers usually do not have adequate information, observability, and technical support to successfully use m-banking. This is attributed to the weak role of banks in this regard (Cruz et al., 2010).

The m-banking service, as a ubiquitous phenomenon, has been extended to include users within the context of Saudi Arabia. According to AVAYA (2017) and SyndiGate (2017), $24 \%$ of Saudi mobile users expressed their intentions to contact their financial institutions via mobile apps. Furthermore, $40 \%$ of Saudi users prefer using their mobiles for all services including m-banking. Also, in case of lack of security and privacy, 52\% of Saudi m-banking users would shift their m-banking use from one bank to another one. In addition, $43 \%$ of them prefer contacting Virtual Financial Advisors (VFAs) through using m-banking for renewing their card details. Moreover, through Vision 2030, the government of Saudi Arabia has embraced and asserted the importance of information systems, including m-banking, in easing the lives of Saudi people. Also, through the NEOM Project, with a budget of nearly half a trillion US dollars on an area of $23000 \mathrm{~km}^{2}$, the Saudi government aims to create a smart city on the national borders between Saudi Arabia, Jordan, and Egypt to be an economic technological hub as enshrined by Crown Prince Mohammad Bin Salman. Thus, it can be deduced that the current and future political direction of Saudi decision makers is to increase the reliance of people on using information technology services including m-banking (CNBC, 2017; Elnakat, 2017; Vision 2030, 2017).

Hence, it is a scientific as well as practical and societal necessity to try to identify factors that influence the continued use of m-banking among users within the context of Saudi Arabia as duly mentioned by Al-Husein and Sadi (2015), Al-Jabri and Sohail (2012), Alkhaldi (2016), Al-Otaibi et al. (2018), Alsheikh and Bojei (2014) and Hidayat-ur-Rehman (2014), who have examined these factors.

This study, however, is unique as it combines two models (i.e. the Technology Acceptance Model (TAM) of Davis (1989) and the Task-Technology Fit (TTF) model of Goodhue and Thompson (1995). In relation to the TAM, this study adopts two variables (i.e. perceived usefulness (USF) and perceived ease of use (EOU)). With regard to the TTF model, this study adopts three variables (i.e. task characteristics, technology characteristics, and TTF). In addition, the study includes two independent factors (i.e. perceived privacy and perceived security). This combination of the two theories and perceived security and perceived privacy 
variables aims to increase the prediction power of the continued intention to use m-banking among Saudi users.

\section{Literature Review}

Identification of the factors which influence continuous intention to use m-banking has been conducted through reliance on a number of theories in the Information Technology and Information Systems field (Shaikh and Karjaluoto, 2015). For instance, Abbas et al. (2018), Al-Husein and Sadi (2015), Chaouali et al. (2017), Mostafa and Eneizan (2018), and Mutahar et al. (2018) implemented an extended TAM; Chawla and Joshi (2018) extended the TAM and Innovation Diffusion Theory (IDT); Lee (2009) integrated Theory of Planned Behaviour (TPB) and the TAM; Al-Jabri and Sohail (2012) and Kapoor et al. (2015) embraced IDT; Yu (2012) embraced the Unified Theory of Acceptance and Use of Technology (UTAUT); and Alalwan et al. (2017) adopted UTAUT2 with trust.

With regard to the TAM, there are extensive studies that used this model in order to examine the factors that influence the continued intention to use m-banking in an international context (e.g. Lee, 2009; Munoz-Leiva et al., 2018; Nasri and Charfeddine, 2012; Yeow et al., 2008). In their systemic review study of 55 articles examining the adoption of m-banking, Shaikh and Karjaluoto (2015) highlighted the fact that the TAM has been the most frequent model applied as theoretical foundation to predict the customers' intention to adopt m-banking. In detail, as stated by Shaikh and Karjaluoto (2015), about 23 studies have employed the TAM and its basic constructs: perceived usefulness and ease of use. Nevertheless, the TAM does not cover the most important aspects which could be considered by customers in forming their intention and decision to use m-banking (Shaikh and Karjaluoto, 2015). And therefore, there are several different factors (i.e. relative advantage, personal innovativeness, perceived risk, perceived cost of use, compatibility, awareness, lifestyle, and perceived security) that have been proposed alongside with TAM constructs (see Shaikh and Karjaluoto, 2015).

In relation to the TTF model, a considerable number of studies have affirmed the power of explanation the TTF model has on individual performance within the context of $\mathrm{m}$ technologies in general (e.g. Junglas et al., 2008), mobile information system studies (e.g. Gebauer and Shaw, 2004; Junglas and Watson 2003; Malaquias et al., 2018; Mehrad and Mohammadi, 2017; Liang and Wei 2004), and m-banking in particular (Gebauer et al., 2005; Lee and Chung, 2009; Lin, 2012; Oliveira et al., 2014; Vatanasombut et al., 2008; Zhou et al., 
2010; Zhou et al., 2010). However, regarding the continued intention to use m-banking within the context of Saudi Arabia, up to date, the application of TTF on m-banking in Saudi Arabia has not been undertaken and, hence, using TTF as a predicting power for examining continued intention to use m-banking is tackled in this study. Moreover, the issue of perceived security as a key factor in influencing continued intention to use m-banking has been thoughtfully examined in the literature (i.e. Haider et al., 2018; Jahangir and Begum, 2008; Kim et al., 2009; Linck et al., 2006; Nie and Hu, 2008; Sharma and Sharma, 2019). Also, perceived privacy was indicated as an efficient predictive factor over continued intention to use m-banking (e.g. Casalo et al., 2007; Choudrie et al., 2018; Jahangir and Begum, 2008; Finn et al., 2013).

Furthermore, various studies tend to combine factors mentioned in two models or more in order to achieve maximum power of prediction of the user's continued intention to use mbanking (e.g. Oliveira et al., 2014; Zhou et al., 2010, Zhou, 2018; Zoghlami et al., 2018). As such, Zhou et al. (2010) combined UTAUT2 and TTF in order to examine m-banking. They found that performance expectancy, social influence, and facilitating conditions from UTAUT and TTF positively impact users' continued intention to use m-banking. Furthermore, Oliveira et al. (2014) combined three models (i.e. UTAUT, and TTF, and the initial trust model (ITM)). After analysing the data of 194 users of m-banking within the context of Portugal, they indicated that facilitating conditions and behavioural intention positively influenced the continuous usage of m-banking. Furthermore, Yuan et al. (2016) adopted a model that combined TTF, the TAM, and perceived risk into the expectanceconfirmation model (ECM) in order to measure the continuous intention to use m-banking within the domain of China. After collecting and analysing the data from 434 m-banking users who already have prior experience, the findings suggest that perceived TTF, perceived usefulness, satisfaction, and perceived risk significantly influence users' continuous intention to use. Furthermore, they found that perceived USF is impacted by perceived EOU, confirmation, and perceived TTF. Nonetheless, they found that perceived EOU does not significantly influence users' continuous intention to use m-banking.

A recent study conducted by Munoz-Leiva et al. (2018) has supported the role of both perceived usefulness and perceived ease of use on customers' attitudes toward m-banking. However, Munoz-Leiva et al. (2018) stated that there was no impact of perceived usefulness on customers' intention to use m-banking. Another recent study by Chaouali et al. (2017) 
asserted the positive role of customers' attitudes in predicting customers' willingness to adopt $\mathrm{m}$-banking in Tunis. In their longitudinal study to test the adoption of m-banking in Brazil, Malaquias et al. (2018) empirically noticed that with the passage of time on the use of mbanking, there is an improvement in the level of consumer perception toward aspects pertaining to task characteristics, trust, ease of use, and social influence. More recently, three factors from the IS success model (information quality, system quality, and service quality) along with trust were proposed by Sharma and Sharma (2019) to predict the customer's intention to use m-banking. Sharma and Sharma (2019) found out that both customers' intention and satisfaction were largely predicted by the role of service quality, information quality, and trust. In their meta-analytic study, they supported the moderation role of power distance on the relationship between social influence and trust with customers' intention to use m-banking. According to the same study of Zhang et al. (2018), individualism has a significant role in moderating the relationship between factors such as performance expectancy, effort expectancy, and perceived risk with customers' intention.

Looking carefully at these studies leads the reader to notice the importance of the benefits perceived in using m-banking as well as the extent to which m-banking is easy to use by customers. In addition, according to the outcomes of these studies, it is important to consider the aspects pertaining to characteristics of the financial tasks performed by m-banking as well as characteristics of m-banking as a technology. Further, m-banking could expose banking customers to a number of issues related to their own information and money privacy and security. Such issues have been largely addressed either generally for online banking channels (i.e. Internet banking) or specifically for m-banking. Therefore, there is always a need to consider these aspects in one single model to see how the customer's attitude, intention, continued intention, or actual adoption could be shaped. More discussion in this regard will be provided in the conceptual model section.

It is also worth mentioning that even though there are a good number of studies that have tested the adoption of m-banking over developing countries (i.e. Malaysia, Singapore, Ghana, Zimbabwe, and India) (see Shaikh and Karjaluoto, 2015), there are few attempts over the Arab countries (i.e. Jordan and Saudi Arabia) (Alalwan et al., 2017; Baabdullah et al., 2019). More specifically, within the context of Saudi Arabia, a small number of studies have focused on the issue of online banking in general (e.g. Alabdan, 2017; Al-Ghaith et al., 2010; AlMalkawi et al., 2016; Al-Somali et al., 2009; Awan et al., 2016) and m-banking in particular 
(i.e. Al-Husein and Sadi, 2015; Al-Jabri and Sohail, 2012, Alkhaldi, 2016; Al-Otaibi et al., 2018; Alsheikh and Bojei, 2014; Hidayat-ur-Rehman, 2014).

In relation to the TAM, Al-Husein and Sadi (2015) adopted an extended TAM that includes self-efficacy, quality of Internet connection, resistance to change, and trust. Their findings show that behavioural intention significantly impacts the continued intention to use $\mathrm{m}$ banking within Saudi Arabia. In addition, Alkhaldi (2016) asserted the importance of perceived security and perceived privacy factors as either deterrent factors that prevent continued intention to use m-banking among Saudi users in cases of perceiving low levels of security and privacy or attracting factors in cases of perceiving high levels of security and privacy. In addition, the findings of Al-Husein and Sadi (2015), which derived from the TAM, indicate that financial centres should emphasise their security features in order to increase the security perceptions of users. This would result in aggregating the level of continued intention to use m-banking within Saudi Arabia. Moreover, through relying on a modified TAM, Alabdan (2017) found that the continued intention to use m-banking among Saudi females is affected by a number of factors (i.e. trust, perceived security, user-friendly, comfortable, and availability). Among the aforementioned factors, Alabdan (2017) indicated that perceived security constitutes the most significant factor over continued intention to use m-banking in Saudi Arabia.

Thus, within the context of Saudi Arabia, there are a few studies that have adopted the TAM, perceived security, and perceived privacy; however, no study used TTF in order to predict continued intention to use m-banking. In the following conceptual model section, the TAM, TTF, perceived security, and perceived privacy will be discussed.

\section{Conceptual Model}

This study adopts a conceptual model that combines four distinctive factors (i.e. factors belonging to the TAM, factors belonging to the TTF model, perceived privacy, and perceived security) as seen in Figure 1.

\section{$<$ Figure 1 about here $>$}

With regard to TTF, strictly speaking, there are two theories in the literature. The theory of TTF was suggested by Goodhue and Thompson (1995) and argues that TTF is an essential idiom in explaining and evaluating information system success. This theory is concerned with 
a person's adoption of information systems and established a predominantly positivistic approach pertinent to information systems in common. Another theory is that of Zigurs and Buckland (1998). It introduces a systematic profile for the combination of task technology between Group Tasks and Group Support Systems. This theory concentrates on the adoption of information systems by groups, rather than individuals, and develops a fit profile applicable particularly to Group Support Systems. This study will consider the theory of Goodhue and Thompson (1995) when examining the TTF model.

Indeed, the TAM considers only two main aspects regarding technology acceptance from the individual perspective: perceived ease of use and perceived usefulness. This, in turn, restricts the ability of the TAM to provide an accurate and comprehensive view about the main aspects predicting the individual's intention and actual adoption of new systems (Agrawal and Prasad, 1999). Accordingly, it has usually been noticed that the TAM is weakly able to predict adequate level of variance in both intention and actual adoption (see Legris et al., 2003; Venkatesh et al., 2003; Venkatesh and Davis, 2000). This could be due to the fact that the TAM model does not cover the impact of individuals' characteristics, technological characteristics, environmental impact, and the role of such factors (privacy and security) (Alalwan et al., 2016; Venkatesh and Davis, 2000; Venkatesh et al., 2003). The main aspects missing in the TAM has been covered in the TTF model, such as task characteristics and technology characteristics, while customers' belief toward aspects of ease of use and usefulness is not covered in the TTF model but addressed by the TAM (Dishaw and Strong, 1999). All things considered have motivated the current study to have an expanded and integrated model considering the TAM, the TTF model, and two other external factors: perceived privacy and perceived security.

Regarding the justification of the integration of the TTF model and the TAM, it can be indicated that this elaboration is provided by the arguments of Goodhue and Thompson (1995) as they made a link between their models and the technology usage model of Bagozzi (1982) (Dishaw and Strong, 1999). Bagozzi's model, which resembles the TAM, was constructed and developed based on attitude and behaviour models to interpret the utilisation of technology (Dishaw and Strong, 1999).

The common argument for putting the TTF model and the TAM into one model is that each one of these models captures two distinctive facets of consumers' selections to utilise information systems (Dishaw and Strong, 1999; Klopping and McKinney, 2004). As such, 
the TAM presumes that attitudes and beliefs of the consumers regarding certain information technology extensively determined whether consumers show the behaviour of utilising the information technology (Goodhue, 1995; Shaikh et al., 2018). The TTF model, however, assumes that users tend to utilise information technology to get benefits such as enhancing their job performance (Lee et al., 2007).

That is to say, users tend repeatedly to adopt information technology when it boosts their work even if they do not like it or have negative attitudes towards it (Lee et al., 2007). From this comparison, it can be deduced that the TTF model adopts an approach that is decidedly rational (Goodhue, 1995). This approach is based on the utilisation of the information system to satisfy job performance rather than considering the attitudes of users towards the technological service (Klopping and McKinney, 2004). Accordingly, choices of the users to utilise an information technology service is impacted by two issues (i.e. their beliefs as duly mentioned by the TAM and their rationale as assumed by the TTF model).

Based on the above-mentioned argument, combining the TAM and TTF model is likely to give a robust explanation on the utilisation of information technology, and this explanation is higher in its accuracy when comparing it with the one that is based on either the TAM or TTF model (Klopping and McKinney, 2004). In addition, this study added perceived security and perceived privacy to the conceptual model due to their substantial roles in sensitive technological services that are related to financial dealings such as m-banking (e.g. Alabdan, 2017; Alkhaldi, 2016; Casalo et al., 2007; Finn et al., 2013; Khasawneh et al., 2018; Linck et al., 2006; Mashhour and Saleh, 2015).

\subsection{Task Characteristics (Task.C) - Task-Technology Fit (TTF)}

Task means "actions" fulfilled by persons in order to turn input into output. Task characteristics include "those [actions] that might move a user to rely more heavily on certain aspects of information technology" (Goodhue and Thompson, 1995, p. 216). There are two main constructs for identifying task characteristics (i.e. "task equivocality" and "task interdependence") (Goodhue and Thompson, 1995, p. 235). Task equivocality aims at dealing with ill-defined business difficulties, ad hoc non-routine business difficulties, and answering new queries in work, while task interdependence focuses on dealing with multi-function business problems (Goodhue and Thompson, 1995). In the model of Fit Focus, Goodhue and Thompson (1995) found that task characteristics positively impact TTF in the field of information technology. With regard to the context of mobile technology, Gebauer et al. 
(2010) indicated that dependency on task characteristics is determined through three parameters (i.e. time, location, and identity). As such, in the context of m-banking when tasks are deeply time-critical, the fit focus of the users would be high when using their mobiles (Zhou et al., 2010). This means that users create a high level of TTF (Zhou et al., 2010). Furthermore, when the characteristic of the task requires a high level of mobility, using mtechnologies would be optimal for doing such tasks as it increases focus on the task (Oliveira et al., 2014). Thus, there is a fit that exists between tasks that is required mobility and using mobiles. Accordingly, task characteristics do positively impact TTF (Gebauer, 2008). Also, in m-banking when the identity of the user does matter for fulfilling the task, the importance of mobile devices would increase as it plays a role in determining the user's identity (Afshan and Sharif, 2016; Oliveira et al., 2014). A prominent example is the recent production of facial recognition technology in iPhone 8 and 8 Plus which might be decisive in future dealing with transactions that are done via mobiles (Dormehl, 2017). Oliveira et al. (2014) and Zhou et al. (2010) asserted the positive role of task characteristics on TTF as it enables the users of an m-banking service to manage their accounts anytime, transfer anytime elsewhere, and have real time control over their accounts as their financial transactions are urgent. Hence, this study proposes that:

H1: Task characteristics have a positive influence on TTF when using m-banking among consumers within the context of Saudi Arabia.

\subsection{Technology Characteristics (Techno.C) - Task-Technology Fit (TTF)}

Technology is defined as "tools" adopted by persons in carrying out their tasks (Goodhue and Thompson, 1995, p. 216). While Goodhue and Thompson (1995) indicated that technology referred to computers as their work is relatively old, Oliveira et al. (2014) and Zhou et al. (2010) indicated that it referred to mobiles. Technology characteristics refer to the traits of technological devices or services used by users in order to fulfil their tasks (Afshan and Sharif, 2016). According to Goodhue and Thompson (1995), technology characteristics significantly influence TTF in the Utilisation Focus Model, where utilisation is about the way in which the jobs are designed and not about the usefulness or quality of the adopted information system. There are a number of studies that investigated the effect of technology characteristics over TTF within the domain of m-banking (e.g. Oliveira et al., 2014; Tam and Oliveira, 2016; Yuan et al., 2016; Zhou et al., 2010). Tam and Oliveira (2016) analysed the data from 256 participants, and they found that technology characteristics affect TTF among the users of m-banking in Portugal. According to Zhou et al. (2010), Oliveira et al. (2014), 
and Yuan et al. (2016), technology characteristics in m-banking impact the TTF, which results in the continued intention to use m-banking technology. Based on the aforementioned discussion, this study suggests that:

H2: Technology characteristics have a positive influence on TTF when using m-banking among consumers within the context of Saudi Arabia.

\subsection{Technology Characteristics (Techno.C) - Perceived Ease of Use (EOU)}

EOU is influenced by the technology characteristics, which include tool experience and tool functionality (Dishaw and Strong, 1999). In detail, increasing the level of functionality would result in making the service easier to use (Yuan et al., 2016). Also, as consumers gain greater experience from their use of the service, the technological service is likely to be easier to use (Dishaw and Strong, 1999). Furthermore, according to Pagani (2006), technology characteristics can positively impact EOU of users when using high-speed data services via mobiles. Within the context of m-banking, Zhou et al. (2010) found that technology characteristics affect consumer effort expectancy, which resembles EOU. Therefore, this study assumes that:

H3: Technology characteristics have a positive influence on users' EOU when using mbanking within the context of Saudi Arabia.

\subsection{Task-Technology Fit (TTF) - Perceived Usefulness (USF)}

If a technological service gives a high level of fit with the task, users would perceive that the adopted service is useful for fulfilling the proposed task (Goodhue and Thompson, 1995). Thus, the positive effect of TTF on USF is derived directly from the definitions of both concepts. A number of studies have found that TTF positively influences USF within the context of mobile technologies (e.g. Chang, 2008; Klopping and McKinney, 2004; Pagani, 2006). According to Yuan et al. (2016), TTF positively impacts perceived USF of Chinese users. Based on this analysis, this study suggests that:

H4: Task-Technology Fit (TTF) has a positive influence on users' USF when using mbanking within the context of Saudi Arabia.

\subsection{Task-Technology Fit (TTF) - Continued Intention (CI)}

The rationale behind using a technological service is that it helps users in performing their tasks well, and this in turn would motivate users to continue using it (e.g. Goodhue and 
Thompson, 1995; Klopping and McKinney, 2004). Accordingly, a high level of TTF would sustain a higher level of continuous intention to use a technological service (e.g. Afshan and Sharif, 2016; Chang, 2008; Pagani, 2006). Within the context of m-banking, Zhou et al. (2010) indicated that TTF positively affects users' continuous intention to use m-banking. Furthermore, Tam and Oliveira (2016) analysed the data from 256 participants, and they found that TTF is an essential precedent that impacts on users' continued intention to use mbanking, particularly when the path of TTF-continued intention to use m-banking is moderated by age. Furthermore, Yuan et al. (2016) found that TTF positively and significantly impacts the continued intention to use m-banking in China. Based on this discussion, this study presumes that:

H5: Task-Technology Fit (TTF) has a positive influence on users' continuous intention when using m-banking within the context of Saudi Arabia.

\subsection{Perceived Usefulness (USF) - Continued Intention (CI)}

USF is defined as "the degree to which a person believes that using a particular system would enhance his or her job performance" (Davis, 1989, p. 320). Kim et al. (2009) suggested that a person often evaluates the consequences of their actions and then establishes a selection reliant on the favourability of perceived USF. Accordingly, USF would impact an individual's intention to use m-banking as a technological service (Dwivedi et al., 2017b; Gumussoy et al., 2018; Williams et al., 2015). Within the domain of m-banking, persons tend to adopt it when perceiving the usefulness of the service for their financial transactions as well as saving their time (Gu et al., 2009; Shaikh and Karjaluoto, 2015; Zhou, 2012). Moreover, banks tend to use m-banking as it would enable them to reduce their physical branches and staff workforce, which in turn reduces their costs (Jeong and Yoon, 2013; Mashhour and Saleh, 2015; Yuan et al., 2016). Within Saudi Arabia, a number of studies affirmed the positive effect of USF on intention to use m-banking among consumers (e.g. AlGhaith et al., 2010; Al-Jabri and Sohail, 2012). Accordingly, this study supposes that:

H6: Perceived usefulness has a positive influence on users' continuous intention when using m-banking within the context of Saudi Arabia.

\subsection{Perceived Ease of Use (EOU) - Continued Intention (CI)}

EOU is defined as "the degree to which a person believes that using a particular system would be free of effort" (Davis, 1989, p. 320). A considerable number of studies have 
indicated that EOU positively impacts the user's continuous intention to use m-banking (e.g. Crabbe et al., 2009; Gu et al., 2009; Laforet and Li, 2005; Mashhour and Saleh, 2015; Priya et al., 2018; Richard and Mandari, 2018). According to Jeong and Yoon (2013), perceiving an m-banking service as easy to use indicates that users felt free from challenge and free from great effort when using it. In contrast, users would denounce continuing use of m-banking when finding that the updates or changes in the service make using it either difficult to learn and/or not easy to use (Hanafizadeh et al., 2014). Therefore, information about m-banking, such as its benefits and guidelines as well as service details, are required to be given in order to make it easier for the users to continue using it (Dwivedi et al., 2016; Dwivedi et al., 2017c; Kim et al., 2009; Rana et al., 2017; Shareef et al., 2012). Within the context of Saudi Arabia, a number of studies examined the positive role of EOU on continuous use of mbanking (e.g. Al-Somali et al., 2008; Sohail and Al-Jabri, 2014). Based on the aforementioned discussion, this study suggests:

H7: Perceived ease of use has a positive influence on intention to use m-banking among consumers within the context of Saudi Arabia.

\subsection{Perceived Security (SR) - Continued Intention (CI)}

Perceived security is defined as "the extent to which a consumer believes that making payments online is secure" (Vijayasarathy, 2004, p. 748). According to Casalo et al. (2007), perceived security is a two-dimensional construct. Firstly, it includes the perceptions of users about the ways of dealing with and protecting personal data in issues of financial services such as m-banking. Secondly, it includes the security of the information technology used in these financial services. With regard to mobile payments, Linck et al. (2006) delineated a division of the idiom of security into subjective and objective security. While objective security addresses the issues of authorisation, confidentiality, integrity, authentication, and non-repudiation, subjective security is perceived security, and it expresses the level to which a user believes that adopting a certain mobile payment method or using m-banking would be secure. Distinctive studies have affirmed the importance of the role of perceived security on continuous intention of customers to use m-banking (e.g. Gu et al., 2009; Laukkanen, 2007; Mashhour and Saleh, 2015). Moreover, studies by Al-Husein and Sadi (2015) and Alkhaldi (2016) focused on the path of perceived security and the user's intention to use in Saudi Arabia. Hence, this study proposes that: 
H8: Perceived security has a positive influence on intention to use m-banking among consumers within the context of Saudi Arabia.

\subsection{Perceived Privacy (PV) - Continued Intention (CI)}

Perceived privacy is defined as the "user's perceptions about the protection of all the data that is collected (with or without users being aware of it) during users' interactions with an Internet banking system" (Wang et al. 2003, p. 503). It explains the view of users about the facet of an information system that focuses on the capacity an individual possesses to determine the type of electronic data that can be shared with third parties (Dwivedi et al., 2017a; Luarn and Lin, 2005). Perceived privacy affects the process of processing, storing, and distributing the electronic information, and this in turn impacts on the intention of users to adopt m-banking privacy (Finn et al., 2013). Indeed, when it comes to financial transactions, privacy becomes of utmost importance in affecting the continuous behaviour of persons as it affects the privacy of the person, the behaviour and action, communication, data and image, thoughts and feelings, location and space, and association (Finn et al., 2013). That is to say, a low level of privacy enables a third party to know the ways in which the mbanking user spends his/her money, his/her debit and credit. Hence, a low level of privacy would deter the continuous use of m-banking as duly mentioned by Akturan and Tezcan (2012). Various studies have highlighted the role of privacy over continuous intention to use m-banking (e.g. Laukkanen, 2007). Within the context of Saudi Arabia, Alsheikh and Bojei (2014) examined the significant role of privacy on users' intention to use m-banking. Based on the previous discussion, this study suggests that:

H9: Perceived privacy has a positive influence on intention to use m-banking among consumers within the context of Saudi Arabia.

\section{Research Methodology}

A field survey using a self-administered questionnaire as a data collection instrument was adopted to collect the required data from a convenience sample of Saudi banking customers from four main cities of the KSA (Riyadh, Jeddah, Mecca, and Medina). In spite of the fact that using the probability sampling technique could avoid a number of problems in terms of sampling bias and results generalisability (Bhattacherjee, 2012), using this kind of probability samples was restricted and difficult in the current study. For instance, it was difficult to capture an inclusive and recent list of all the users of m-banking technology in the KSA. This 
is one of the most fundamental elements required in the sample frame to use the probability sampling technique (Bhattacherjee, 2012; Dwivedi et al., 2006). Banks in Saudi Arabia never allow information (i.e. contact numbers, addresses, emails) to be given regarding their customers. All things considered, the convenience sampling technique was selected as a more appropriate technique for the current study population (Castillo, 2009; Dwivedi et al., 2006). As for the four cities considered in the current study, Riyadh, Jeddah, Mecca, and Medina are the largest cities in the KSA respectively. The actual population size of these cities are as follows: Riyadh: 6,506,700; Jeddah: 3,976,400; Mecca: 1,919,900; and Medina: 1,271,800 (Worldatlas, 2018). Further, these cities geographically represent all parts of the KSA. Riyadh is the political capital in the south; Jeddah is in the east of the KSA; Mecca is the capital city of the Hejaz province in the KSA; and Madina is the fourth largest city in the KSA (Worldatlas, 2018).

This study was conducted over the period from December 2017 till the end of February 2018. As the study aims to test customers' continued intention to use m-banking, it targeted the actual users of m-banking who have used such a system. Importantly, it also considered the m-banking services delivered using specific kinds of mobile applications provided by banks. Five hundred banking customers who have used m-banking were allocated questionnaires using several techniques. A large number of those participants were approached by their banks while others were accessed at their work places (Dwivedi et al., 2006).

The questionnaire consists of three parts (i.e. cover page (research's aim and researchers' information), participant's demographic profile (age, gender, occupation and income) and constructs' items derived from the relevant literature (30 scale items) - See Appendix. For example, both perceived USF and EOU were measured using items extracted from Davis et al. (1989). Items of the TTF model constructs were adopted from Zhou et al. (2010) and Lin and Huang (2008). The main items of privacy and security were derived from Vijayasarathy (2004) and Casalo et al. (2007). As Arabic is the main language in the KSA, the questionnaire was translated from English to Arabic using the back-translation method suggested by Brislin (1976). Then, the Arabic version of the questionnaire was judged by a panel of experts at the department of Management Information System (MIS) and marketing in the King Abdulaziz University who are fluent in both Arabic and English (Dwivedi et al., 2006). After that, a pilot study with 30 master students at the Business School in the King Abdulaziz University was conducted to see if there was any problem regarding the language used as well as to test the factors reliability (Dwivedi et al., 2006). Most participants 
mentioned that the language used was clear and there were no vague sentences. Factors reliability was tested using Cronbach's alpha as suggested by Nunnally (1978), and all values were found to be higher than 0.70 (Nunnally, 1978).

\subsection{Treatment of Missing Data}

As recommended by Churchill (1995), the amount of missing data was examined in addition to their distribution pattern. The yielded results showed that the percentage of the missing values for each construct was within the recommended level $(<5 \%)$. Furthermore, the p value ( $\mathrm{p}=.785)$ of missing completely at random (MCAR) was non-significant (Churchill, 1995). This ensures the random pattern of the missing data values (non-systematically distributed) (Little, 1988). Accordingly, all the missing data values were filled by the mean value of each variable (Hair et al., 2010; Tabachnick and Fidell, 2007).

\section{Results}

\subsection{Response Rate and Participants' Characteristics}

Out of the 500 questionnaires that were allocated, 352 were returned. Out of these, 320 questionnaires were found to be completed and valid, and accordingly these 320 that were subjected to further analyses. As seen in Table 1, among the 320 participants, 189 of them are male $(59.1 \%)$ while 131 are female $(40.9 \%)$. The largest number of participants $(215 ; 67.2 \%)$ is noted to be within the age group of 21-29 followed by the age group 30-39 (44; 13.8\%). About $178(55.6 \%)$ of the respondents are public sector employees while $60(18.8 \%)$ are private sector employees. One hundred and forty (43.8\%) have monthly income ranging between 8001 and 14000 Saudi Riyals followed by those who have monthly income between 4001 and 8000 Saudi Riyals.

\section{<Table 1 about here>}

\subsection{Structural Equation Modelling}

Two stages of structural equation modelling (SEM) were applied using AMOS 22. In the first stage, measurement model, confirmatory factor analyses (CFA) were tested to ensure adequate level of model fitness as well as to attain construct reliability and validity. Then, the proposed model and research hypotheses were targeted in the second stage: structural model analyses.

The CFA was tested firstly, and the initial fit indices of the measurement model (i.e. CMIN/DF was 3.214, GFI $=0.851, \mathrm{AGFI}=0.751, \mathrm{NFI}=0.894, \mathrm{CFI}=0.905$, and $\mathrm{RMSEA}=$ 
0.085) indicated that the model has poor fit (see Table 2). Therefore, the main problematic items were removed from the revised version of the measurement model (see Table 3). These problematic items were found to be as follows: one item from SR and two items from PV. All of these items were found to have a factor loading less than 0.50 and accordingly were dropped from the revised version of the measurement model. The fit indices of the revised measurement model were found to be as follows: $\mathrm{CMIN} / \mathrm{DF}=2.365, \mathrm{GFI}=0.912$, $\mathrm{AGFI}=$ $0.861, \mathrm{NFI}=0.947, \mathrm{CFI}=0.974$, and $\mathrm{RMSEA}=0.064$. This proved the goodness of fit of the measurement model at this time (Anderson and Gerbing, 1988; Hair et al., 2010).

\section{<Table 2 about here>}

As seen in Table 4, all constructs were found to have composite reliability (CR) value higher than 0.70 as suggested by Hair et al. (2010). The highest value of CR (0.985) was recorded for Techno.C whereas the lowest one (0.821) was for Task.C. As for the average variance extracted (AVE), all constructs have also been recorded as having an acceptable value higher than 0.50 as suggested by Hair et al. (2010). The AVE values range from 0.606 for Task.C to 0.956 for Techno.C. Finally, the discriminant validity was ensured in the current study as all inter-correlation values between constructs are less than the squared root of AVE value of the targeted construct (Kline, 2011).

\section{<Table 3 about here >}

\section{<Table 4 about here>}

At the second stage, the structural model was tested to see the fitness of the proposed model to the observed data and to verify the main causal relationships hypothesised. Statistically, the model seems to adequately fit the observed data as all fit indices were observed to be within their cut-off values $(\mathrm{CMIN} / \mathrm{DF}=2.932, \mathrm{GFI}=0.906, \mathrm{AGFI}=0.842, \mathrm{NFI}=0.934, \mathrm{CFI}=$ 0.961 , and RMSEA $=0.068$ ). As seen in Figure 2, the $R^{2}$ values were found as such: .58 for continued intention, .48 for TTF, .31 for usefulness, and .35 for ease of use. This, in turn, supports the predictive validity of the current proposed model.

\section{<Figure 2 about here>}

The main results of path coefficient analyses are presented in Table 5. Accurately, USF $(\gamma=$ $0.49, \mathrm{p}<0.000)$, TTF $(\gamma=0.25, \mathrm{p}<0.000)$, SR $(\gamma=0.21, \mathrm{p}<0.000)$, and PV $(\gamma=0.15, \mathrm{p}<0.000)$ significantly predict intention to continue to use m-banking. TTF was found to be strongly affected by Task.C $(\gamma=0.38, \mathrm{p}<0.000)$ and Techno.C $(\gamma=0.12, \mathrm{p}<0.028)$. TTF has a positive influence on USF $(\gamma=0.48, p<0.000)$. Techno.C also significantly predicts EOU $(\gamma=0.60$, 
$\mathrm{p}<0.000)$. However, EOU $(\gamma=0.10, \mathrm{p}<0.135)$ was not able to have a significant impact on the intention to continue use. Accordingly, all research hypotheses, H1, H2, H3, H4, H5, H6, H8, and $\mathrm{H} 9$, are accepted while $\mathrm{H} 7$ alone was rejected.

\section{<Table 5 about here >}

\section{Discussion}

As presented in the prior section, 'Results', this study was able to empirically support what has been discussed and proposed in the conceptual model. Researchers were keen to clarify how Saudi bank customers are interested in continuing to use m-banking as well as discover the main factors that could shape the perception of Saudi bank customers toward such innovative technology. The statistical results largely supported the predictive validity of the current study model. For example, about .58, .48, .31, .35 of variance were accounted continued intention, TTF, USF, and EOU sequentially. Such values were found to be more than the .30 that was suggested by Arambewela and Hall (2009), Holmes-Smith et al. (2006), and Kline (2011), and also these values are very similar to other studies that have tested the adoption of m-banking such as Foon and Fah (2011), who accounted .56 of variance in behavioural intention to use m-banking and Zhou et al. (2010), whose model predicted about .57 of variance in the adoption behaviour.

Such results extracted in the current study largely support the selection of both the TTF model and the TAM to propose the current study model. This also gives clues that such integration between the TTF model and the TAM could provide an accurate picture regarding the continued intention to adopt m-banking in the KSA as a developing country. Furthermore, excluding the path between EOU and CI, all proposed paths discussed in the conceptual model and literature review have been supported. In the following paragraphs, the current study results regarding each hypothesis are discussed more in light of the current study data as well as what has been discussed over the literature review and proposed in the conceptual model.

According to path coefficient analyses, perceived USF was observed to be the strongest factor predicting Saudi customers' continued intention to use m-banking. This means that Saudi customers largely value m-banking as a more useful and productive technology making their interaction with their banks much easier and more efficient. One of the main reasons behind this is the nature of m-banking as movable technology enabling customers to access a wide range of banking services without any time and place restrictions. To put it differently, 
as a kind of mobile technology, m-banking is enjoyed with a high level of mobility and ubiquity in comparison with other online or traditional banking channels. This means that mbanking enhances customers' ability to access banking services whenever and wherever they need. Accordingly, by using m-banking, customers are more able to save their time and effort in comparison to the traditional way of accessing m-banking via human encounter. In fact, there are a wide range of financial services (i.e. balance enquiries and downloading bank statements, funds transfer, and paying bills) that customers can access 24/7 from anywhere. Further, as mentioned in the introduction section, the nature of m-banking, which supports the consumer in relying on himself/herself and without any human interaction, also supports the level of privacy and security. Such results of USF are very similar to those reached by prior m-banking studies (i.e. Hanafizadeh et al., 2014; Wessels and Drennan, 2010).

TTF was also the second largest significant factor predicting Saudi customers' continued intention to use m-banking. This is in addition to the significant impact of TTF on USF. As long as m-banking can provide the targeted users with an adequate and high-quality level of functions and tasks that match their requirements, they are more likely to perceive using such technology as more useful in their daily life and accordingly they will be more interested in using this technology in future (Dwivedi et al., 2015). Indeed, the statistical results of the current study indicate that Saudi customers see m-banking as having a higher level of TTF, which positively reflects on their perception and intention to use m-banking in future. Different studies have extracted similar results to these attained in the current study (i.e. Chang, 2008; Klopping and McKinney, 2004; Pagani, 2006; Zhou et al., 2010).

The task characteristics construct was shown to have a significant impact on the TTF as presented in the results section. The main dimensions of any functions that customers need to accomplish regarding banking transactions will directly reflect on the TTF of the technology that helps customers to perform these functions. In fact, with the pressure of time and responsibilities, people seem to be more engaged with their banking. More specifically, customers currently need to have an interactive and constant communication with their banks. And accordingly, they are demanding more facilities to access banking services. This is in addition to the sensitive necessity for financial transactions that customers need to conduct continuously. In this respect, and according to Tam and Oliveira (2016) and Zhou et al. (2010), customers' requirements to manage, control, and conduct banking services whenever and wherever they are largely shape their perception of TTF related to using m-banking technology. 
Technology characteristics were found to be a very crucial factor in the conceptual model as both TTF and EOU are largely influenced by this construct. As discussed above, compared with other bank channels (human encounter, ATM, and Internet banking) (Hanafizadeh et al., 2014), m-banking has several features that make customers more attracted to such a system and more positively value it either in terms of EOU or of TTF. For instance, there is the ubiquitous nature of m-banking that enables customers to access a wide range of banking services, at the time needed, quickly and safely. This, in turn, positively reflects the quality of the functions performed using m-banking as well as the usefulness and ease of use perceived in such technology. Such results are consonant with these found by Oliveira et al. (2014), Tam and Oliveira (2016), Yuan et al. (2016), and Zhou et al. (2010).

Both privacy and security were observed to have a significant impact on Saudi customers' continued intention to use m-banking. To put it differently, banking customers in the KSA seem to be more concerned regarding their own privacy and the level of security when they are in the process of using m-banking applications. This could be attributed to the sensitive nature of financial transactions overall and especially those conducted via online applications such as m-banking (Alalwan et al., 2017; Dwivedi et al., 2017a). Therefore, customers will pay more attention to tools and mechanisms to securely undertake financial transactions using mobile technology (Casalo et al., 2007; Vijayasarathy, 2004). Some aspects, such as authorisation, confidentiality, integrity, authentication, and non-repudiation, are very important in m-banking applications to let customers perceive that using these systems is secure and safe enough (Gu et al., 2009; Laukkanen, 2007; Mashhour and Saleh, 2015). By the same token, in order to use m-banking, the customer is requested to disclose important and personal information. This, in turn, could raise the customer's concerns regarding their own privacy especially due to the fact that some data could be shared with third parties (Luarn and Lin, 2005). Theoretically, there are a good number of studies that have supported the role of both security and privacy in customers' continued intention to use m-banking (i.e. Akturan and Tezcan, 2012; Finn et al., 2013; Laukkanen, 2007; Luarn and Lin, 2005).

In contrast with what has been proposed regarding the role of ease of use, Saudi customers seem to be not concerned about the level of easiness or difficulty in using m-banking. This could simply be due to the fact that m-banking has been increasingly becoming more adopted and technologies have been becoming better known as well as customers being more experienced in interacting with m-banking. This is in addition to the fact that the current study participants are actual users of m-banking and enjoy a certain level of experience in 
using it. Thus, they are less concerned regarding any difficulties that could be found in using m-banking. Moreover, even if there are some difficulties in using it, customers are more interested in using such systems as long as they highly value m-banking in terms of usefulness and TTF as for participants of the current study sample (Castañeda et al., 2007; Davis et al., 1989; Venkatesh et al., 2003; Venkatesh et al., 2012; Wang et al., 2006; Wessels and Drennan, 2010). Over the prior literature, there are a number of studies that have disproved the role of ease of use or similar factors such as effort expectancy, for example Brown et al. (2003), Wessels and Drennan (2010), Wu and Wang (2005), Yu (2012), and Zhou et al. (2010).

\subsection{Theoretical and Practical Implications}

This study early noted the importance of discovering and testing the main dimensions that could shape customers' perception and continued intention to use m-banking in the KSA. As discussed in the introduction section, the related issues of m-banking have received less attention by researchers over the developing countries especially in the KSA. Thus, this study represents a worthy attempt to test such technology (m-banking) in the KSA where there is a scarcity of literature. In fact, most studies that have tested the related issues of m-banking adoption simply considered the potential adopters and their intention toward such adoption. Other studies have considered the current usage behaviour. However, customers' continued intention has rarely been tested using a solid theoretical foundation considering models such as the TTF model and the TAM. Therefore, a considerable theoretical contribution was made by integrating the TTF model with the TAM in addition to considering privacy and security in one single model. In detail, careful reviewing of the current literature of m-banking leads to noticing a need to discover what the key mechanisms that could shape the customer's perception toward the functionality and fitness of the technology. This has been covered in the current study by testing the impact of task characteristics and technology characteristics on the TTF.

Furthermore, the current literature of m-banking does not cover well the role of TTF in shaping the customers' perceived usefulness. This study accordingly comprises another contribution by proposing and empirically validating such relationship between TTF and USF. Further, this study proposes a new relationship between technology characteristics and perceived EOU. This relationship has been less examined in the prior studies, which, in turn, comprises another contribution made by the current study. Moreover, considering both perceived privacy and security in the current model creates an accurate picture about the 
adoption of $\mathrm{m}$-banking especially as there are a limited number of $\mathrm{m}$-banking studies that have considered privacy and security alongside the TTF model and the TAM in the same model.

Practically, this study could offer marketers and service providers clues that could help them to improve the key aspects that are considered by Saudi customers with respect to m-banking. For instance, the study supports that role of privacy and security, and accordingly, marketers and m-banking service providers have to focus more on enhancing the customer's perception that using m-banking is a safe channel to access banking services. In this regard, different mechanisms (biometric technology, authentication, and encryption) could be used by banks to ensure the level of security in any banking transaction conducted using m-banking. As well as this, banks should ensure the level of privacy related to any information provided by customers in order to use m-banking. Therefore, banks have to express their concern regarding the privacy of information provided by customers. In this respect, banks also have to ensure their moral and legal system is protecting the customer's personal information. Indeed, banks' attitude to the importance of privacy and security in m-banking services will also contribute to the customer's perception for the related issues of TTF.

Results of the current study also show the importance of technology characteristics in shaping the customer's perception toward ease of use and TTF. Thus, marketers and m-banking designers have to pay more attention to the main aspects of mobile technology. For example, the ubiquitous nature of mobile technology should be more accelerated to guarantee that customers can access m-banking services from wherever they are. This could call banks to collaborate more with mobile service providers to maintain their networks and geographical coverage. Banks also should ensure the quality and reliability of m-banking services as well as fix any problem that could hinder accessibility to such services. A m-banking platform with a friendly and simple design could also help with quick and easy use of m-banking services. Task characteristics were also the focus of attention of customers. Marketing campaigns should accelerate the customer perception that m-banking is a more flexible and adaptable channel to access banking services in comparison with traditional banking channels. Further, customers could have more controllability via using m-banking. It could be important to ensure the fit of m-banking services to the customer's requirements and needs. This could be enhanced by providing a wide range of banking services through m-banking as well as by ensuring its appropriateness to the new customer's lifestyle and work needs. 


\section{Conclusion}

The related issues of m-banking have received little attention by researchers in the KSA. Therefore, this study was conducted to fill this gap and to provide researchers and practitioners with clues about the main dimensions that have to be considered to guarantee a better understanding about factors predicting the customer's intention and adoption of $\mathrm{m}$ banking, and accordingly, having a successful implementation for such technology. Therefore, based on a critical review of the main body of literature either in m-banking or in the IS area overall, the researchers have successfully proposed an integrated model from the TAM and TTF model which was also expanded by including privacy and security. This study examines customers' continued intention to use m-banking; therefore, the actual users of mbanking were targeted in the current study sample. Data was collected using a convenience sample of m-banking users from four main cities of the KSA (Riyadh, Jeddah, Mecca, and Medina). The data was then tested using SEM, and the main results largely support the predictive validity of the current study model. Accurately, TTF, USF, SR, and PV were able to predict about .58 of variance in the customers' continued intention to use m-banking. Based on the current results, this paper has discussed the main theoretical and practical implications as presented in the prior section.

\section{Research Limitations and Future Directions}

Even though this study represents a valuable attempt to address the adoption of m-banking over emerging countries, there are still a number of concerns that restrict it. For example, the moderation influence of the demographic factors (i.e. age, gender, income level, educational level) is not tested. Thus, it could be more useful to see how the current study model yields different indicators by considering the moderation influence of the demographic factors (Haider et al., 2018). The study also does not consider the impact of personal and psychological factors (i.e. innovativeness, self-efficacy, perceived behavioural control, need for interaction). Accordingly, future studies could add value by testing these aspects. As a consumer technology, the role of hedonic motivation and price value is very critical, yet it was not considered in the current study. It would be very important to consider these hedonic and monetary aspects in future studies. The data was collected using a self-report questionnaire; however, it would be more accurate to utilise more statistics from the bank database about the users of m-banking. Finally, this study just examined the customers' continued use of m-banking; however, the outcomes of using m-banking on the customers' 
actual use behaviour and customers' satisfaction would provide a comprehensive picture about the successful implementation of m-banking technology in the KSA.

\section{References}

Abbas, S. K., Hassan, H. A., Asif, J., Junaid, H. M., and Zainab, F. (2018). What are the key determinants of mobile banking Adoption in Pakistan? International Journal of Scientific \& Engineering Research, 9(2), 841-848.

Adholiya, A., Dave, P., and Adholiya, S. (2012). Determinants of customer satisfaction for mobile banking services-an empirical evidence from public and private sector banks at Udaipur, Rajasthan. International Journal of Applied Services Marketing Perspectives, 1(1), 1-6.

Afshan, S. and Sharif, A. (2016). Acceptance of mobile banking framework in Pakistan. Telematics and Informatics, 33(2), 370-387.

Agrawal, R. and Prasad, J. (1999). Are individual differences germane to the acceptance of new information technologies?. Decision Sciences, 30(2), 361-391.

Akturan, U. and Tezcan, N. (2012). Mobile banking adoption of the youth market: Perceptions and intentions. Marketing Intelligence \& Planning, 30(4), 444-459.

Alabdan, R. (2017). The Adoption of Online Banking With Saudi Arabian Banks: A Saudi Female Perspective. Journal of Internet Banking and Commerce, 22(S8).

Alalwan, A. A., Dwivedi, Y. K., and Rana, N. P. (2017). Factors influencing adoption of mobile banking by Jordanian bank customers: Extending UTAUT2 with trust. International Journal of Information Management, 37(3), 99-110.

Alalwan, A. A., Dwivedi, Y. K., Rana, N. P., and Williams, M. D. (2016). Consumer adoption of mobile banking in Jordan: Examining the role of usefulness, ease of use, perceived risk and self-efficacy. Journal of Enterprise Information Management, 29(1), 118-139.

Al-Ghaith, W., Sanzogni, L., and Sandhu, K. (2010). Factors influencing the adoption and usage of online services in Saudi Arabia. The Electronic Journal of Information Systems in Developing Countries, 40(1), 1-32.

Al-Husein, M. and Sadi, M. A. (2015). Preference on the perception of mobile banking: A Saudi Arabian Perspective. European Online Journal of Natural and Social Sciences, 4(1), 161.

Al-Jabri, I. M. and Sohail, M. S. (2012). Mobile Banking Adoption: Application of Diffusion of Innovation Theory. Journal of Electronic Commerce Research, 13(4): 379-391.

Alkhaldi, A. N (2016). Adoption of Mobile Banking In Saudi Arabia: An Empirical Evaluation Study. International Journal of Managing Information Technology, $8(2): 1-14$.

Al-Malkawi, H. A. N., Mansumitrchai, S., and Al-Habib, M. (2016). Online banking in an emerging market: evidence from Saudi Arabia. International Journal of Electronic Finance, 9(1), 1-17. 
Al-Otaibi, S., Aljohani, N. R., Hoque, M. R., and Alotaibi, F. S. (2018). The Satisfaction of Saudi Customers Toward Mobile Banking in Saudi Arabia and the United Kingdom. Journal of Global Information Management (JGIM), 26(1), 85-103.

Alsheikh, L. and Bojei, J. (2014). Determinants affecting customer's intention to adopt mobile banking in Saudi Arabia. International Arab Journal of e-Technology, 3(4), 210-219.

Al-Somali, S. A., Gholami, R., and Clegg, B. (2009). An investigation into the acceptance of online banking in Saudi Arabia. Technovation, 29(2), 130-141.

Al-Somali, S. A., Gholami, R., and Clegg, B. (2008). Internet Banking Acceptance in the Context of Developing Countries: An Extension of the Technology Acceptance Model. In European Conference on Management of Technology, Nice, France.

Anderson, J. C. and Gerbing, D. W. (1988). Structural equation modelling in practice: A review and recommended two-step approach. Psychological Bulletin, 103(3), 411423.

Apple Pay (2017). Cashless made effortless. Available at: https://www.apple.com/apple-pay/. Accessed: 23.1.2018.

Arambewela, R., and Hall, J. (2009). An empirical model of international student satisfaction. Asia Pacific Journal of Marketing and Logistics, 21(4), 555-569.

AVAYA (2017). Saudi Customers Opt for Mobile Banking. Available at: https://www.avaya.com/en/perspectives/posts/banking-customers-in-saudi-arabiaprefer-mobile-banking-poll-9556344/. Accessed: 2.11.2017.

Awan, M. A., Khan, H. U., and Chiang, H. H. (2016). Online banking: a comparative study of Chinese and Saudi customers perceptions of service quality. The Journal of Internet Banking and Commerce (Vol. 21, no. S5, pp. 1-31).

Baabdullah, A. M., Alalwan, A. A., Rana, N. P., Kizgin, H., and Patil, P. (2019). Consumer use of mobile banking (M-Banking) in Saudi Arabia: Towards an integrated model. International Journal of Information Management, 44, 38-52.

Bagozzi, R. P. (1982). A field investigation of causal relations among cognitions, affect, intentions, and behavior. Journal of Marketing Research, 562-583.

Bannister, D. (2014). The name's Paym - UK Payments Council names mobile service. Available at: http://www.bankingtech.com/208562/the-names-paym-uk-paymentscouncil-names-mobile-service/. Accessed: 24.10.2017.

Barclays (2017). Barclays pingit. Available at: https://www.barclays.mobi/BarclaysPingit/MP1242629610109. Accessed: 24.10.2017.

Bhattacherjee, A. (2012). Social science research: Principles, methods, and practices. $\left(2^{\text {nd }}\right.$ Ed.). Florida, USA: AnolBhattacherjee.

Board of Governors of the Federal Reserve System (2013). Consumers and Mobile Financial Services. Available at: https://www.federalreserve.gov/econresdata/consumers-andmobile-financial-services-report-201303.pdf. Accessed: 1.11.2017.

Brislin, R. (1976). Comparative research methodology: Cross-cultural studies. International Journal of Psychology, 11(3), 215-229. 
British Bankers' Association (2015). An App Elite for Banking. Available at: https://www.bba.org.uk/. Accessed: 1.11.2017.

Brown, M., Pope, N., and Voges, K. (2003). Buying or browsing? An exploration of shopping orientations and online purchase intention. European Journal of Marketing, 37(10/11), 1666-1684.

Casalo, L. V., Flavián, C., and Guinalíu, M. (2007). The role of security, privacy, usability and reputation in the development of online banking. Online Information Review, 31(5), 583-603.

Castañeda, J. A., Muñoz-Leiva, F., and Luque, T. (2007). Web Acceptance Model (WAM): Moderating effects of user experience. Information \& Management, 44(4), 384-396.

Castillo, J. J. (2009). Population sampling techniques. Available at: https://explorable.com/ simple-random-sampling. Accessed: 17.10.2018.

Cellan-Jones, R. (2016). Android Pay in UK: A tipping point for mobile payments? BBC news/technology. Available at: http://www.bbc.co.uk/news/technology-36320321. Accessed: 22.10.2017.

Chang, H. H. (2008). Intelligent agent's technology characteristics applied to online auctions' task: A combined model of TTF and TAM. Technovation, 28(9), 564-577.

Chaouali, W., Souiden, N., and Ladhari, R. (2017). Explaining adoption of mobile banking with the theory of trying, general self-confidence, and cynicism. Journal of Retailing and Consumer Services, 35, 57-67.

Chawla, D. and Joshi, H. (2018). The Moderating Effect of Demographic Variables on Mobile Banking Adoption: An Empirical Investigation. Global Business Review, 19(3_suppl), S90-S113.

Choudrie, J., Junior, C. O., McKenna, B., and Richter, S. (2018). Understanding and conceptualising the adoption, use and diffusion of mobile banking in older adults: A research agenda and conceptual framework. Journal of Business Research, 88, 449465.

Churchill, G. A. (1995). Marketing research methodological foundation. (6 ${ }^{\text {th }}$ Ed.). Orlando, Florida: The Dryden Press.

CNBC (2017). Global Investing Hot Spots: Saudis set $\$ 500$ billion plan to develop zone linked with Jordan and Egypt. Available at: https://www.cnbc.com/2017/10/24/saudis-500-billion-plan-to-neom-businesscity.html. Accessed: 26.10.2017.

Coetzee, L. and Eksteen, J. (2011, May). The Internet of Things-promise for the future? An introduction. In IST-Africa Conference Proceedings (pp. 1-9). IEEE.

Crabbe, M., Standing, M., Standing, C. S., and Karjaluoto, H. (2009). An Adoption Model for Mobile Banking in Ghana. International Journal of Mobile Communications, 7(5), 515-543.

Cruz, P., Neto, L. B. F., Munoz-Gallego, P., and Laukkanen, T. (2010). Mobile banking rollout in emerging markets: Evidence from Brazil. International Journal of Bank Marketing, 28(5), 342-371.

Davis, F. D. (1989). Perceived usefulness, perceived ease of use, and user acceptance of information technology. MIS Quarterly, 319-340. 
Deloitte LLP UK member firm of DTT (2016). There's no place like phone, Consumer usage patterns in the era of peak smartphone, Global Mobile Consumer Survey 2016: UK Cut. Available at: http://www.deloitte.co.uk/mobileuk/. Accessed: 22.10.2017.

Dishaw, M. T. and Strong, D. M. (1999). Extending the technology acceptance model with task-technology fit constructs. Information \& Management, 36(1), 9-21.

Dormehl, L. (2017). iPhone 8's amazing facial recognition is super quick, works in the dark. Available at: https://www.cultofmac.com/498426/iphone-8s-amazing-facialrecognition-super-quick-works-dark/. Accessed: 23.10.2017.

Dwivedi, Y. K., Choudrie, J., and Brinkman, W. P. (2006). Development of a survey instrument to examine consumer adoption of broadband. Industrial Management \& Data Systems, 106(5), 700-718.

Dwivedi, Y. K., Janssen, M., Slade, E. L., Rana, N. P., Weerakkody, V., Millard, J., ... and Snijders, D. (2017a). Driving innovation through big open linked data (BOLD): Exploring antecedents using interpretive structural modelling. Information Systems Frontiers, 19(2), 197-212.

Dwivedi, Y. K., Rana N. P., Janssen, M., Lal, B., Williams, M. D., and Clement, R. M. (2017b). An Empirical Validation of a Unified Model of Electronic Government Adoption (UMEGA). Government Information Quarterly, 34(2), 211-230.

Dwivedi, Y. K., Rana, N. P., Jeyaraj, A., Clement, M., and Williams, M. D. (2017c). Reexamining the unified theory of acceptance and use of technology (UTAUT): Towards a revised theoretical model. Information Systems Frontiers, 1-16. DoI: https://doi.org/10.1007/s10796-017-9774-y

Dwivedi, Y. K., Shareef, M. A., Simintiras, A. C., Lal, B., and Weerakkody, V. (2016). A generalised adoption model for services: A cross-country comparison of mobile health (m-health). Government Information Quarterly, 33(1), 174-187.

Dwivedi, Y. K., Wastell, D., Laumer, S., Henriksen, H. Z., Myers, M. D., Bunker, D., ... and Srivastava, S. C. (2015). Research on information systems failures and successes: Status update and future directions. Information Systems Frontiers, 17(1), 143-157.

Elnakat, M. (2017). Digital banking outlook in Saudi Arabia promising. Saudi Gazette. Available at: http://saudigazette.com.sa/article/516015/BUSINESS/Saudi-Arabia. Accessed: 23.10 .2017$.

Finn, R. L., Wright, D., and Friedewald, M. (2013). Seven types of privacy. In European data protection: coming of age (pp. 3-32). Springer Netherlands.

Foon, Y. S. and Fah, B. C. Y. (2011). Internet banking adoption in Kuala Lumpur: An application of the UTAUT model. International Journal of Business \& Management, 6(4), 161-167.

Gebauer, J. (2008). User requirements of mobile technology: A summary of research results. Information Knowledge Systems Management, 7(1, 2), 101-119.

Gebauer, J. and Shaw, M. J. (2004). Success factors and impacts of mobile business applications: Results from a mobile e-procurement study. International Journal of Electronic Commerce, 8(3), 19-41.

Gebauer, J., Shaw, M. J., and Gribbins, M. L. (2010). Task-technology fit for mobile information systems. Journal of Information Technology, 25(3), 259-272. 
Gebauer, J., Shaw, M. J., and Gribbins, M. L. (2005). Towards a specific theory of tasktechnology fit for mobile information systems. University of Illinois at UrbanaChampaign, College of Business Working Paper, 05-0119.

Goodhue, D. L. (1995). Understanding user evaluations of information systems. Management Science, 41(12), 1827-1844.

Goodhue, D. L. and Thompson, R. L. (1995). Task-technology fit and individual performance. MIS Quarterly, 213-236.

Gu, J. C., Lee, S. C., and Suh, Y. H. (2009). Determinants of Behavioral Intention to Mobile Banking. Expert Systems with Applications, 36(9), 11605-11616.

Gumussoy, C. A., Kaya, A., and Ozlu, E. (2018). Determinants of Mobile Banking Use: An Extended TAM with Perceived Risk, Mobility Access, Compatibility, Perceived Selfefficacy and Subjective Norms. In Industrial Engineering in the Industry 4.0 Era (pp. 225-238). Springer, Cham.

Haider, M. J., Changchun, G., Akram, T., and Hussain, S. T. (2018). Exploring Gender Effects in Intention to Islamic Mobile Banking Adoption: an empirical study. Arab Economic and Business Journal, 13(1), 25-38.

Hair Jr., J. F., Black, W. C., Babin, B. J., and Anderson, R. E. (2010). Multivariate data analysis: A global perspective. ( $7^{\text {th }}$ Ed.). Pearson Education International.

Hanafizadeh, P., Behboudi, M., Koshksaray, A. A., and Tabar, M. J. S. (2014). Mobilebanking adoption by Iranian bank clients. Telematics and Informatics, 31(1), 62-78.

Hidayat-ur-Rehman, I. (2014). Mobile Banking Adoption in Saudi Arabia. Asian Journal of Research in Banking and Finance, 4(10), 300-310.

Holmes-Smith, P., Coote, L., and Cunningham, E. (2006). Structural equation modelling: From the fundamentals to advanced topics. Melbourne: School Research, Evaluation and Measurement Services.

Isac, A. (2013). Use of mobile technology in banking services. Annals of the University of Petrosani, Economics, 13(2),109-116.

Jahangir, N. and Begum, N. (2008). The role of perceived usefulness, perceived ease of use, security and privacy, and customer attitude to engender customer adaptation in the context of electronic banking. African Journal of Business Management, 2(2), 32.

Jeong, B. K. and Yoon, T. E. (2013). An empirical investigation on consumer acceptance of mobile banking services. Business and Management Research, 2(1), 31.

Junglas, I., Abraham, C., and Watson, R. T. (2008). Task-technology fit for mobile locatable information systems. Decision Support Systems, 45(4), 1046-1057.

Junglas, I. A. and Watson, R. T. (2003). U-commerce: a conceptual extension of e-commerce and $\mathrm{m}$-commerce. Proceedings of the Twenty-Fourth International Conference on Information Systems (ICIS 2003). Seattle, Washington, 667-677.

Kapoor, K. K., Dwivedi, Y. K., and Williams, M. D. (2015). Examining the role of three sets of innovation attributes for determining adoption of the interbank mobile payment service. Information Systems Frontiers, 17(5), 1039-1056.

Kaymaz, F. (2017). Overview of Approaches in the United Kingdom. In Mobile Payment (pp. 243-257). Springer Gabler, Wiesbaden. 
Khasawneh, M. H. A., Hujran, O., and Abdrabbo, T. (2018). A quantitative examination of the factors that influence users' perceptions of trust towards using mobile banking services. International Journal of Internet Marketing and Advertising, 12(2), 181-207.

Kim, G., Shin, B., and Lee, H. G. (2009). Understanding dynamics between initial trust and usage intentions of mobile banking. Information Systems Journal, 19(3), 283-311.

Kline, R. B. (2011). Principles and practice of structural equation modelling. New York: The Guilford Press.

Klopping, I. M. and McKinney, E. (2004). Extending the technology acceptance model and the task-technology fit model to consumer e-commerce. Information Technology, Learning, and Performance Journal, 22(1), 35.

Laforet, S. and Li, X. (2005). Consumers' attitudes towards online and mobile banking in China. International Journal of Bank Marketing, 23(5), 362-380.

Laukkanen, T. (2007). Internet vs mobile banking: comparing customer value perceptions. Business Process Management Journal, 13(6), 788-797.

Laukkanen, T. and Cruz, P. (2009). Comparing consumer resistance to Mobile banking in Finland and Portugal. E-Business and Telecommunications. 48, 89-98.

Laukkanen, T. and Pasanen, M. (2008). Mobile banking innovators and early adopters: How they differ from other online users? Journal of Financial Services Marketing, 13(2), 86-94.

Laukkanen, T., Sinkkonen, S., Kivijärvi, M., and Laukkanen, P. (2007). Innovation resistance among mature consumers. The Journal of Consumer Marketing, 24(7), 419-427.

Lee, C. C., Cheng, H. K., and Cheng, H. H. (2007). An empirical study of mobile commerce in insurance industry: Task-technology fit and individual differences. Decision Support Systems, 43(1), 95-110.

Lee, H., Harindranath, G., Oh, S., and Kim, D. J. (2015). Provision of mobile banking services from an actor-network perspective: Implications for convergence and standardization. Technological Forecasting and Social Change, 90, 551-561.

Lee, K. C. and Chung, N. (2009). Understanding factors affecting trust in and satisfaction with mobile banking in Korea: A modified DeLone and McLean's model perspective. Interacting with Computers, 21(5), 385-392.

Lee, M. C. (2009). Factors influencing the adoption of Internet banking: An integration of TAM and TPB with perceived risk and perceived benefit. Electronic Commerce Research and Applications, 8(3), 130-141.

Legris, P., Ingham, J., and Collerette, P. (2003). Why do people use information technology? A critical review of the technology acceptance model. Information and Management, 40(3), 191-204.

Liang, T.-P. and Wei, C. (2004). Introduction to the special issue: mobile commerce applications. International Journal of Electronic Commerce, 8(3) 7-17.

Lin, H. F. (2011). An empirical investigation of mobile banking adoption: The effect of innovation attributes and knowledge-based trust. International Journal of Information Management, 31(3), 252-260.

Lin, H. F. (2013). Determining the relative importance of mobile banking quality factors. Computer Standards \& Interfaces, 35(2), 195-204. 
Lin, T. C. and Huang, C. C. (2008). Understanding knowledge management system usage antecedents: An integration of social cognitive theory and task technology fit. Information \& Management, 45(6), 410-417.

Lin, W. S. (2012). Perceived fit and satisfaction on web learning performance: IS continuance intention and task-technology fit perspectives. International Journal of Human-Computer Studies, 70(7), 498-507.

Linck, K., Pousttchi, K., and Wiedemann, D. G. (2006). Security Issues in Mobile Payment from the Customer Viewpoint. In Ljungberg, J. (Ed.), Proceedings of the 14th European Conference on Information Systems (ECIS 2006). Göteborg, Sweden, pp. 111.

Little, R. J. (1988). A test of missing completely at random for multivariate data with missing values. Journal of the American Statistical Association, 83(404), 1198-1202.

Luarn, P. and Lin, H. H. (2005). Toward an understanding of the behavioral intention to use mobile banking. Computers in Human Behavior, 21(6), 873-891.

Malaquias, F., Malaquias, R., and Hwang, Y. (2018). Understanding the determinants of mobile banking adoption: A longitudinal study in Brazil. Electronic Commerce Research and Applications, 30, 2018 1-7.

Martin, C. (2016). What is Mondo Bank? Mondo Bank review: The app-only smart Mondo card, now called Monzo. PCAdvisor. Available at: http://www.pcadvisor.co.uk/buying-advice/gadget/what-is-mondo-bank-mondobank-review-app-only-smart-mondo-card-monzo3644615/\#Mondo\%20bank\%20review. Accessed: 22.10.2017.

Mashhour, A. S. and Saleh, Z. (2015). Community Perception of the Security and Acceptance of Mobile Banking Services in Bahrain: An Empirical Study. International Journal of Advanced Computer Science and Applications, 6(9), 45-54.

Mehrad, D. and Mohammadi, S. (2017). Word of Mouth impact on the adoption of mobile banking in Iran. Telematics and Informatics, 34(7), 1351-1363.

Mishra, V. and Bisht, S. (2013). Mobile banking in a developing economy: A customercentric model for policy formulation. Telecommunications Policy, 37(6), 503-514.

Mostafa, A. A. and Eneizan, B. (2018). Factors Affecting Acceptance of Mobile Banking in Developing Countries. International Journal of Academic Research in Business and Social Sciences, 8(1), 340-351.

Mullan, J., Bradley, L., and Loane, S. (2017). Bank adoption of mobile banking: stakeholder perspective. International Journal of Bank Marketing, 35(7), 1154-1174.

Munoz-Leiva, F., Climent-Climent, S., and Liébana-Cabanillas, F. (2018). Determinants of intention to use the mobile banking apps: An extension of the classic TAM model. Spanish Journal of Marketing-ESIC, 21(1), 25-38.

Mutahar, A. M., Daud, N. M., Thurasamy, R., Isaac, O., and Abdulsalam, R. (2018). The Mediating of Perceived Usefulness and Perceived Ease of Use: The Case of Mobile Banking in Yemen. International Journal of Technology Diffusion (IJTD), 9(2), 2140.

Nasri, W. and Charfeddine, L. (2012). Factors affecting the adoption of Internet banking in Tunisia: An integration theory of acceptance model and theory of planned behavior. The Journal of High Technology Management Research, 23(1), 1-14. 
Nie, J. and Hu, X. (2008, December). Mobile banking information security and protection methods. In International Conference on Computer Science and Software Engineering (Vol. 3, pp. 587-590). IEEE.

Nunnally, J. C. (1978). Psychometric theory. New York, NY: McGraw-Hill.

Oliveira, T., Faria, M., Thomas, M. A., and Popovič, A. (2014). Extending the understanding of mobile banking adoption: When UTAUT meets TTF and ITM. International Journal of Information Management, 34(5), 689-703.

Pagani, M. (2006). Determinants of adoption of high speed data services in the business market: evidence for a combined technology acceptance model with task technology fit model. Information \& Management, 43(7), 847-860.

Pay by Bank app (2016). Wirecard forges strategic partnership with VocaLink to open up Pay by Bank app to merchants and boon's mobile payment customers. Available at: https://paybybankapp.co.uk/wirecard-forges-strategic-partnership-vocalinkopen-pay-bank-app-merchants-boons-mobile-payment-customers/. Accessed: 26.10.2017.

Priya, R., Gandhi, A. V., and Shaikh, A. (2018). Mobile banking adoption in an emerging economy: An empirical analysis of young Indian consumers. Benchmarking: An International Journal, 25(2), 743-762.

Rana, N. P., Dwivedi, Y. K., Lal, B., Williams, M. D., and Clement, M. (2017). Citizens' adoption of an electronic government system: towards a unified view. Information Systems Frontiers, 19(3), 549-568.

Richard, E. and Mandari, E. (2018). Factors Influencing Usage Of Mobile Banking Services: The Case Of Ilala District In Tanzania. Orsea Journal, 7(1).

Rolfe, A. (2015). Zapp launch Pay by Bank app mobile payment paymark. Payments Cards \& Mobile. Available at: http://www.paymentscardsandmobile.com/zapp-launch-payby-bank-app-mobile-payment-paymark/. Accessed: 26.10.2017.

Santander Bank (2017). Mobile Banking. Retrieved on November 2017, 4: http://www.santander.co.uk/uk/help-support/mobile-banking

Shaikh, A. A. and Karjaluoto, H. (2015). Mobile banking adoption: A literature review. Telematics and Informatics, 32(1), 129-142.

Shaikh, A. A., Glavee-Geo, R., and Karjaluoto, H. (2018). How relevant are risk perceptions, effort, and performance expectancy in mobile banking adoption? International Journal of E-Business Research, 14(2).

Shareef, M. A., Archer, N., and Dwivedi, Y. K. (2012). Examining adoption behavior of mobile government. Journal of Computer Information Systems, 53(2), 39-49.

Shareef, M. A., Baabdullah, A., Dutta, S., Kumar, V., and Dwivedi, Y. K. (2018). Consumer adoption of mobile banking services: An empirical examination of factors according to adoption stages. Journal of Retailing and Consumer Services, 43, 54-67.

Shareef, M. A., Dwivedi, Y. K. Stamati, T., and Williams, M. D. (2014). SQ mGov: A comprehensive service-quality paradigm for Mobile government. Information Systems Management, 31(2), 126-142.

Sharma, S. K. and Al-Muharrami, S. (2018). Mobile Banking Adoption: Key Challenges and Opportunities and Implications for a Developing Country. In Emerging Markets from a Multidisciplinary Perspective (pp. 75-86). Springer, Cham. 
Sharma, S. K. and Sharma, M. (2019). Examining the role of trust and quality dimensions in the actual usage of mobile banking services: An empirical investigation. International Journal of Information Management, 44, 65-75.

Singh, S. and Srivastava, R. K. (2018). Predicting the intention to use mobile banking in India. International Journal of Bank Marketing, 36(2), 357-378.

Slade, E. L., Dwivedi, Y. K., Piercy, N. C., and Williams, M. D. (2015a). Modeling consumers' adoption intentions of remote mobile payments in the United Kingdom: extending UTAUT with innovativeness, risk, and trust. Psychology \& Marketing, 32(8), 860-873.

Slade, E., Williams, M., Dwivedi, Y., and Piercy, N. (2015b). Exploring consumer adoption of proximity mobile payments. Journal of Strategic Marketing, 23(3), 209-223.

Sohail, M. S. and Al-Jabri, I. M. (2014). Attitudes towards mobile banking: are there any differences between users and non-users? Behaviour \& Information Technology, 33(4), 335-344.

Statista (2017). Gross transaction volume (GMV) of mobile banking in China from 2011 to 2018 (in trillion yuan). Available at: https://www.statista.com/statistics/450091/mobile-banking-transaction-volume-inchina/. Accessed: 2.11.2017.

SyndiGate (2017). Premium digital content for Arabia and beyond. Available at: http://www.syndigate.info/. Accessed: 2.11.2017.

Tabachnick, B. G. and Fidell, L. S. (2007) Using multivariate statistics. (5 ${ }^{\text {th }}$ Ed.). Boston: Pearson Education.

Tam, C. and Oliveira, T. (2016). Performance impact of mobile banking: using the tasktechnology fit (TTF) approach. International Journal of Bank Marketing, 34(4), 434457.

Vatanasombut, B., Igbaria, M., Stylianou, A. C., and Rodgers, W. (2008). Information systems continuance intention of web-based applications customers: The case of online banking. Information \& Management, 45(7), 419-428.

Venkatesh, V. and Davis, F. D. (2000). A theoretical extension of the technology acceptance model: Four longitudinal field studies. Management Science, 46(2), 186-204.

Venkatesh, V., Morris, M. G., Davis, G. B., and Davis, F. D. (2003). User acceptance of information technology: Toward a unified view. MIS Quarterly, 425-478.

Venkatesh, V., Thong, J. Y., and Xu, X. (2012). Consumer acceptance and use of information technology: extending the unified theory of acceptance and use of technology. MIS Quarterly, 157-178.

Vijayasarathy, L. R. (2004). Predicting consumer intentions to use on-line shopping: the case for an augmented technology acceptance model. Information \& Management, 41(6), 747-762.

Vision 2030 (2017). Saudi Vision 2030. Available at: http://vision2030.gov.sa/en. Accessed: 26.10.2017.

Wang, Y. S., Lin, H. H., and Luarn, P. (2006). Predicting consumer intention to use mobile service. Information Systems Journal, 16(2), 157-179. 
Wang, Y. S., Wang, Y. M., Lin, H. H., and Tang, T. I. (2003). Determinants of user acceptance of Internet banking: an empirical study. International Journal of Service Industry Management, 14(5), 501-519.

Wessels, L. and Drennan, J. (2010). An investigation of consumer acceptance of M-banking. International Journal of Bank Marketing, 28(7), 547-568.

Williams, M. D., Rana, N. P., and Dwivedi, Y. K. (2015). The unified theory of acceptance and use of technology (UTAUT): a literature review. Journal of Enterprise Information Management, 28(3), 443-488.

Worldatlas. (2018). Biggest Cities In Saudi Arabia. Available at: https://www.worldatlas.com/articles/biggest-cities-in-saudi-arabia.html. Accessed: 25.10 .2018 .

Wu, J. H. and Wang, S. C. (2005). What drives Mobile commerce? An empirical evaluation of the revised technology acceptance model. Information \& Management, 42(5), 719729.

Yang, A, S. (2009). Exploring adoption difficulties in mobile banking services. Canadian Journal of Administrative Sciences, 26(2), 136-149.

Yeow, P. H., Yuen, Y. Y., Tong, D. Y. K., and Lim, N. (2008). User acceptance of online banking service in Australia. Communications of the IBIMA, 1(22), 191-197.

Yu, C. S. (2012). Factors affecting individuals to adopt mobile banking: Empirical evidence from the UTAUT model. Journal of Electronic Commerce Research, 13(2), 104.

Yuan, S., Liu, Y., Yao, R., and Liu, J. (2016). An investigation of users' continuance intention towards mobile banking in China. Information Development, 32(1), 20-34.

Zhang, Z., Warren, C. M., Lei, Y., Xing, Q., and Li, H. (2018). Commentary: Are groups more or less than the sum of their members? The moderating role of individual identification. Frontiers in psychology, 9.

Zhou, T. (2011). An empirical examination of initial trust in Mobile banking. Internet Research, 21(5), 527-540.

Zhou, T. (2012). Examining mobile banking user adoption from the perspectives of trust and flow experience. Information Technology and Management, 13(1), 27-37.

Zhou, T. (2018). Examining users' switch from online banking to mobile banking. International Journal of Networking and Virtual Organisations, 18(1), 51-66.

Zhou, T., Lu, Y., and Wang, B. (2010). Integrating TTF and UTAUT to explain mobile banking user adoption. Computers in Human Behavior, 26(4), 760-767.

Zigurs, I. and Buckland, B. K. (1998). A theory of task/technology fit and group support systems effectiveness. MIS Quarterly, 313-334.

Zoghlami, A. T., Yahia, K. B., and Berraies, S. (2018). From Mobile Service Quality Evaluation to E-Word-Of-Mouth: What Makes the Users of Mobile Banking Applications Speak About the Bank?: The Moderating Role of Brand Reputation. International Journal of E-Services and Mobile Applications (IJESMA), 10(2), 36-57. 
Table 1: Participant Demographics

\begin{tabular}{|c|c|c|c|}
\hline \\
\hline \multicolumn{2}{|c|}{ Participants' Characteristics } & Frequency & Percent \\
\hline \multirow{6}{*}{ Monthly income (Saudi Riyals) } & $1000-4000$ & 24 & 7.5 \\
\hline & $4001-8000$ & 71 & 22.2 \\
\hline & $8001-14000$ & 140 & 43.8 \\
\hline & $14001-20000$ & 60 & 18.8 \\
\hline & More than 20000 & 25 & 7.8 \\
\hline & Total & 320 & 100.0 \\
\hline \multirow{5}{*}{ Occupation } & Student & 41 & 12.8 \\
\hline & Government employee & 178 & 55.6 \\
\hline & Private sector employee & 60 & 18.8 \\
\hline & Self-employed & 41 & 12.8 \\
\hline & Total & 320 & 100.0 \\
\hline \multirow[t]{3}{*}{ Gender } & Male & 189 & 59.1 \\
\hline & Female & 131 & 40.9 \\
\hline & Total & 320 & 100.0 \\
\hline \multirow[t]{6}{*}{ Age } & $>=18-20$ & 37 & 11.6 \\
\hline & $21-29$ & 215 & 67.2 \\
\hline & $30-39$ & 44 & 13.8 \\
\hline & $40-49$ & 20 & 6.3 \\
\hline & 50 and above & 4 & 1.3 \\
\hline & Total & 320 & 100.0 \\
\hline
\end{tabular}

Table 2: Results of Measurement Model

\begin{tabular}{|c|c|c|c|}
\hline \\
\hline Fit indices & Cut-off point & Initial measurement model & Modified measurement model \\
\hline CMIN/DF & $\leq 3.000$ & 3.214 & 2.365 \\
\hline GFI & $\geq 0.90$ & 0.851 & 0.912 \\
\hline AGFI & $\geq 0.80$ & 0.751 & 0.861 \\
\hline NFI & $\geq 0.90$ & 0.894 & 0.947 \\
\hline CFI & $\geq 0.90$ & 0.905 & 0.974 \\
\hline RMSEA & $\leq 0.08$ & 0.085 & 0.064 \\
\hline
\end{tabular}


Table 3: Standardised Regression Weights

\begin{tabular}{|c|c|c|c|c|c|}
\hline Construct & Measurement Items & Estimate & Construct & Measurement Items & Estimate \\
\hline \multirow[t]{4}{*}{ USF } & USF1 & .902 & \multirow[t]{3}{*}{$\mathrm{PV}$} & PV1 & .887 \\
\hline & USF2 & .835 & & PV2 & .706 \\
\hline & USF3 & .835 & & PV3 & .848 \\
\hline & USF4 & .789 & \multirow[t]{3}{*}{ Techno.C } & Techno.C1 & .983 \\
\hline \multirow[t]{3}{*}{ SR } & SR1 & .994 & & Techno.C2 & .971 \\
\hline & SR2 & .853 & & Techno.C3 & .979 \\
\hline & SR3 & .594 & \multirow[t]{4}{*}{ EOU } & EOU1 & .870 \\
\hline \multirow[t]{3}{*}{ Task.C } & Task.C1 & .823 & & EOU2 & .870 \\
\hline & Task.C2 & .687 & & EOU3 & .885 \\
\hline & Task.C3 & .817 & & EOU4 & .908 \\
\hline \multirow[t]{3}{*}{ TTF } & TTF1 & .955 & \multirow[t]{3}{*}{$\mathrm{CI}$} & CI1 & .919 \\
\hline & TTF2 & .755 & & $\mathrm{CI} 2$ & .907 \\
\hline & TTF3 & .661 & & $\mathrm{CI} 3$ & .904 \\
\hline
\end{tabular}

Table 4: Construct Reliability and Validity

\begin{tabular}{|l|c|c|c|c|c|c|c|c|c|c|}
\hline & CR & AVE & SR & Task.C & TTF & CI & PV & USF & Techno.C & EOU \\
\hline SR & 0.865 & 0.689 & $\mathbf{0 . 8 3 0}$ & & & & & & & \\
\hline Task.C & 0.821 & 0.606 & 0.125 & $\mathbf{0 . 7 7 8}$ & & & & & & \\
\hline TTF & 0.901 & 0.700 & 0.165 & 0.280 & $\mathbf{0 . 8 3 7}$ & & & & & \\
\hline CI & 0.935 & 0.828 & 0.448 & 0.407 & 0.559 & $\mathbf{0 . 9 1 0}$ & & & & \\
\hline PV & 0.857 & 0.668 & 0.163 & 0.129 & 0.164 & 0.321 & $\mathbf{0 . 8 1 7}$ & & & \\
\hline USF & 0.906 & 0.708 & 0.220 & 0.264 & 0.548 & 0.701 & 0.207 & $\mathbf{0 . 8 4 1}$ & & \\
\hline Techno.C & 0.985 & 0.956 & 0.265 & 0.151 & 0.193 & 0.370 & 0.108 & 0.214 & $\mathbf{0 . 9 7 8}$ & \\
\hline EOU & 0.934 & 0.780 & 0.138 & 0.242 & 0.244 & 0.366 & 0.094 & 0.401 & 0.594 & $\mathbf{0 . 8 8 3}$ \\
\hline
\end{tabular}

Note: Diagonal values are squared roots of AVE; off-diagonal values are the estimates of inter-correlation

between the latent constructs. 
Table 5: Results of Standardised Estimates

\begin{tabular}{|l|l|l|l|}
\hline Hypothesised path & Standardised estimate & P-value & Significance \\
\hline $\mathrm{USF} \rightarrow \mathrm{CI}$ & 0.49 & $* * *$ & Sig \\
\hline $\mathrm{TTF} \rightarrow \mathrm{CI}$ & 0.25 & $* * *$ & $\mathrm{Sig}$ \\
\hline $\mathrm{TTF} \rightarrow \mathrm{USF}$ & 0.48 & $* * *$ & Sig \\
\hline $\mathrm{EOU} \rightarrow \mathrm{CI}$ & 0.10 & 0.135 & Non-Sig \\
\hline $\mathrm{PV} \rightarrow \mathrm{CI}$ & 0.15 & $* * *$ & Sig \\
\hline $\mathrm{SR} \rightarrow \mathrm{CI}$ & 0.21 & $* * *$ & Sig \\
\hline Task.C $\rightarrow$ TTF & 0.38 & $* * *$ & Sig \\
\hline Techno.C $\rightarrow$ TTF & 0.12 & 0.028 & Sig \\
\hline Techno.C $\rightarrow$ EOU & 0.60 & $* * *$ & Sig \\
\hline
\end{tabular}




\begin{tabular}{|c|c|c|c|}
\hline Construct & & Items & Source \\
\hline \multirow[t]{4}{*}{ Perceived Usefulness } & PU1 & I find mobile banking useful in my daily life. & \multirow[t]{7}{*}{ Davis et al. (1989) } \\
\hline & PU2 & $\begin{array}{l}\text { Using mobile banking increases my chances of achieving tasks that are important to } \\
\text { me. }\end{array}$ & \\
\hline & PU3 & Using mobile banking helps me accomplish tasks more quickly. & \\
\hline & PU4 & Using mobile banking increases my productivity. & \\
\hline \multirow{3}{*}{$\begin{array}{l}\text { Perceived } \\
\text { Ease of Use }\end{array}$} & EOU1 & Learning how to use mobile banking is easy for me. & \\
\hline & EOU2 & My interaction with mobile banking is clear and understandable. & \\
\hline & EOU3 & I find mobile banking easy to use. & \\
\hline \multirow{3}{*}{ Task Characteristics } & Task.C1 & I need to manage my account anytime anywhere. & \multirow[t]{6}{*}{ Zhou et al. (2010) } \\
\hline & Task.C2 & I need to transfer money anytime anywhere. & \\
\hline & Task.C3 & I need to acquire account information in real time. & \\
\hline \multirow{3}{*}{$\begin{array}{l}\text { Technology } \\
\text { Characteristics }\end{array}$} & Techno.C1 & Mobile banking provides ubiquitous services. & \\
\hline & Techno.C2 & Mobile banking provides real-time services. & \\
\hline & Techno.C3 & Mobile banking provides secure services. & \\
\hline \multirow[t]{3}{*}{ Technology Task Fit } & TTF1 & The functionalities of mobile banking are very adequate. & \multirow[t]{3}{*}{ Lin and Huang (2008) } \\
\hline & TTF2 & The functionalities of mobile banking are very appropriate. & \\
\hline & TTF4 & The functions of mobile banking fully meet my banking needs. & \\
\hline \multirow[t]{5}{*}{ Perceived Privacy } & PV1 & I feel safe when I send personal information to mobile banking. & \multirow[t]{8}{*}{ Casalo et al. (2007) } \\
\hline & PV2 & I think mobile banking abides by personal data protection laws. & \\
\hline & PV3 & $\begin{array}{l}\text { I think mobile banking only collects user personal data that are necessary for its } \\
\text { activity. }\end{array}$ & \\
\hline & PV4 & $\begin{array}{l}\text { I think mobile banking respects the user's rights when obtaining personal } \\
\text { information. }\end{array}$ & \\
\hline & PV5 & $\begin{array}{l}\text { I think that mobile banking will not provide my personal information to other } \\
\text { companies without my consent. }\end{array}$ & \\
\hline \multirow[t]{4}{*}{ Perceived Security } & SR1 & $\begin{array}{l}\text { I think mobile banking has mechanisms to ensure the safe transmission of its users' } \\
\text { information. }\end{array}$ & \\
\hline & SR2 & I think mobile banking shows great concern for the security of any transactions. & \\
\hline & SR3 & $\begin{array}{l}\text { When I send data to mobile banking, I am sure that they will not be intercepted by } \\
\text { unauthorised third parties. }\end{array}$ & \\
\hline & SR4 & In general, making transactions on mobile banking is secure. & Vijayasarathy (2004) \\
\hline
\end{tabular}




\begin{tabular}{|l|l|l|l|}
\hline Continued Intention & CI1 & I intend to continue using mobile banking in the future. & Venkatesh et al. (2012) \\
\cline { 2 - 4 } & CI2 & I will always try to use mobile banking in my daily life. \\
\cline { 2 - 3 } & CI3 & I plan to continue to use mobile banking frequently. \\
\hline
\end{tabular}

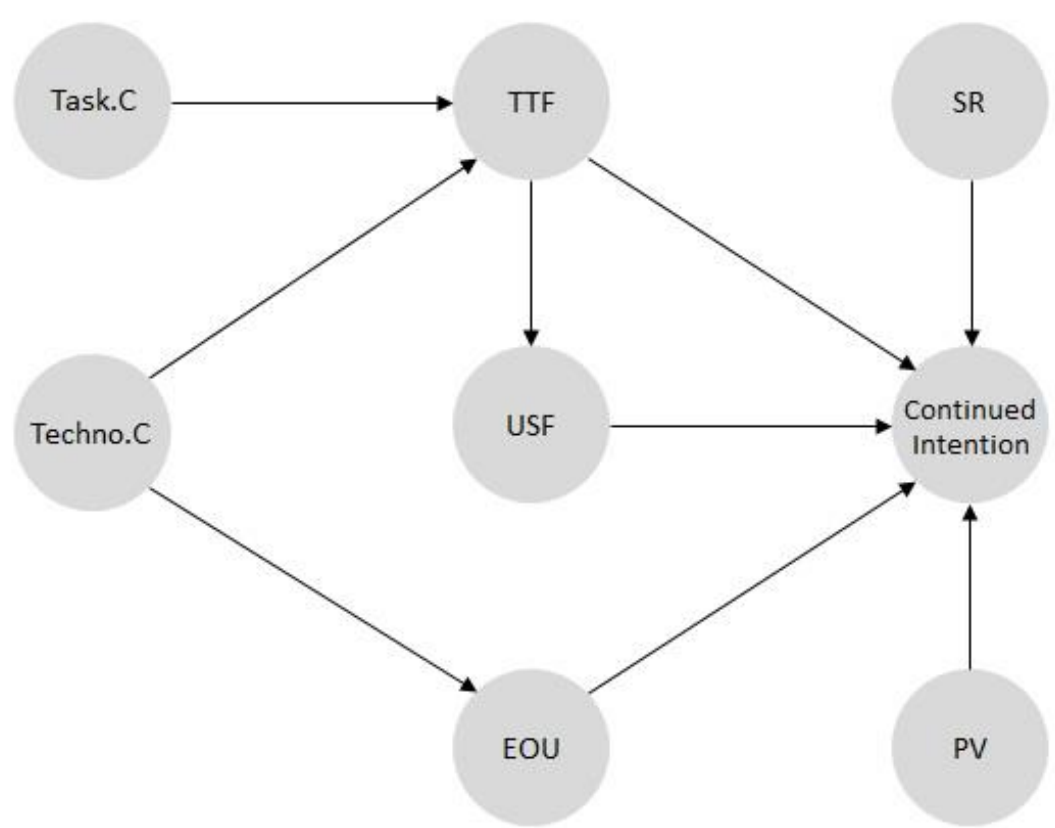

Figure 1: Conceptual Model - Adopted from Davis et al. (1989), Goodhue and Thompson (1995), Vijayasarathy (2004), and Wang et al. (2003)

[Task.C: Task Characteristics, Techno.C: Technology Characteristics, TTF: Task-Technology Fit, USF: Perceived Usefulness, EOU: Perceived Ease of Use, SR: Perceived Security, PV: Perceived Privacy, CI: Continued Intention] 


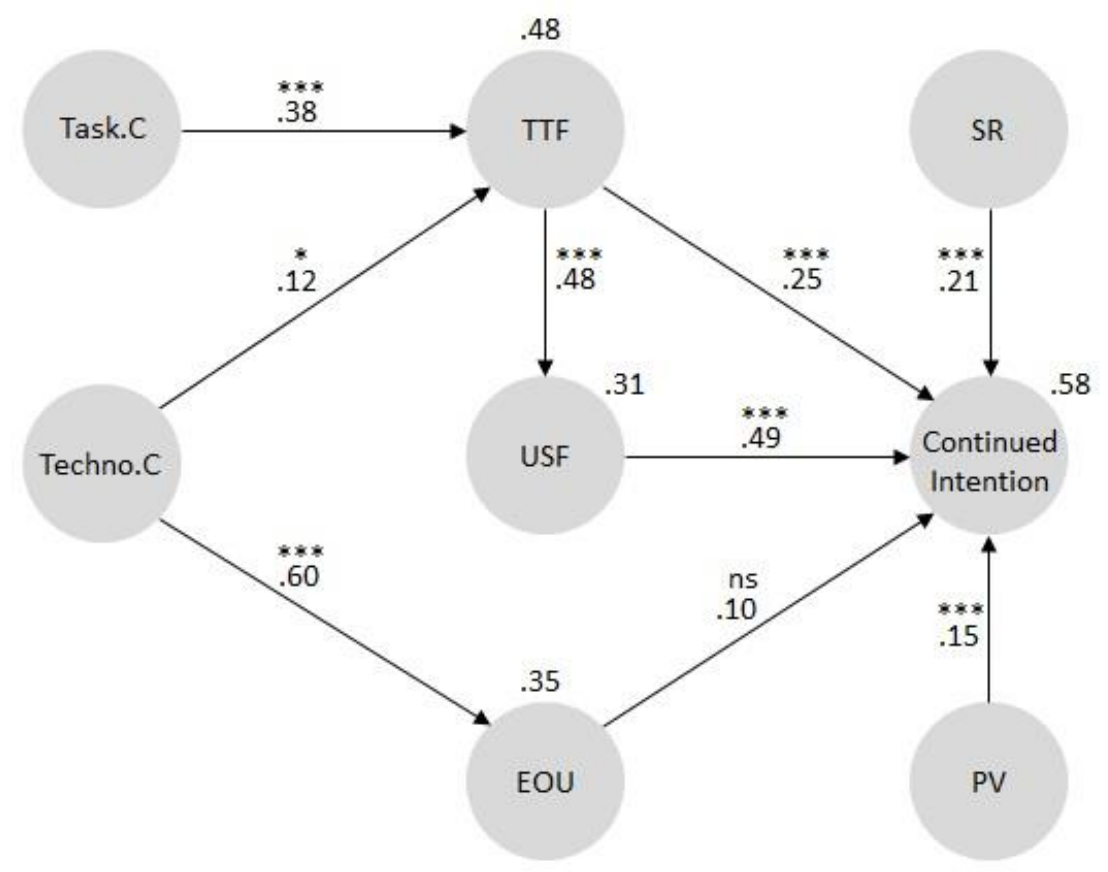

Figure 2: Validation of the Conceptual Model

[ns: $\mathrm{P}>0.05, *: \mathrm{P} \leq 0.05, * *: \mathrm{P} \leq 0.01, * * *: \mathrm{P} \leq 0.001]$ 